\title{
Current status and perspectives of patient-derived xenograft models in cancer research
}

\author{
Yunxin Lai ${ }^{1,2}$, Xinru Wei ${ }^{1,2}$, Shouheng Lin ${ }^{1,2}$, Le Qin ${ }^{1,2}$, Lin Cheng ${ }^{1,2}$ and Peng Li ${ }^{1,2,3^{*}}$
}

\begin{abstract}
Cancers remain a major public health problem worldwide, which still require profound research in both the basic and preclinical fields. Patient-derived xenograft (PDX) models are created when cancerous cells or tissues from patients' primary tumors are implanted into immunodeficient mice to simulate human tumor biology in vivo, which have been extensively used in cancer research. The routes of implantation appeared to affect the outcome of PDX research, and there has been increasing applications of patient-derived orthotopic xenograft (PDOX) models. In this review, we firstly summarize the methodology to establish PDX models and then go over recent application and function of PDX models in basic cancer research on the areas of cancer characterization, initiation, proliferation, metastasis, and tumor microenvironment and in preclinical explorations of anti-cancer targets, drugs, and therapeutic strategies and finally give our perspectives on the future prospects of PDX models.
\end{abstract}

Keywords: PDX models, Basic, Preclinical, Cancer research, Drugs

\section{Background}

Cancers are among the leading causes of death worldwide. The Cancer Moonshot 2020 program has been launched in 2016 to transform the cancer research and care ecosystem and double the rate of progress in cancer prevention, diagnosis, and treatment [1], though success achieved in reducing cancer death rates in the USA [2]. This program envisaged the development of precision medicine based on five critical elements-clinical bioinformatics, precision methods, disease-specific biomarkers, drug discovery and development, and precision regulations-to guard the application of precision medicine [3]. Novel techniques and research tools would play important roles in this process.

Patient-derived xenograft (PDX) models are immunodeficient mice engrafted with patients' cancerous cells or

\footnotetext{
* Correspondence: li_peng@gibh.ac.cn

'Key Laboratory of Regenerative Biology, South China Institute for Stem Cell Biology and Regenerative Medicine, Guangzhou Institutes of Biomedicine and Health, Chinese Academy of Sciences, Guangzhou 510530, China ${ }^{2}$ Guangdong Provincial Key Laboratory of Stem Cell and Regenerative Medicine, South China Institute for Stem Cell Biology and Regenerative Medicine, Guangzhou Institutes of Biomedicine and Health, Chinese Academy of Sciences, Guangzhou 510530, China

Full list of author information is available at the end of the article
}

tissues. The development of PDX models for cancer research, based on the assumption that these models faithfully resemble the original tumors, especially for the patient-derived orthotopic xenograft (PDOX) models [4], has significantly enhanced cancer research in recent years. These models for various types of cancers, such as chronic lymphocytic leukemia [5], large B cell lymphoma [6], pancreatic cancer [7], colorectal cancer [7, 8], gastric cancer [9, 10], high-grade serous carcinoma [11], and intrahepatic cholangiocarcinoma [12], are biologically stable and accurately reflect the patients' tumors with regard to histopathology, gene expression, genetic mutations, inflammation [13], and therapeutic response. Thus, PDX models allow invaluable assessment of human tumor biology, identification of therapeutic targets, and preclinical screening and evaluation of drugs for various cancers. In this review, we summarize the methodology to establish PDX models (Fig. 1), go over the recent advances of basic cancer studies and preclinical studies in which PDX models have been used (Fig. 2), and give our perspectives on the future prospects of PDX models. 

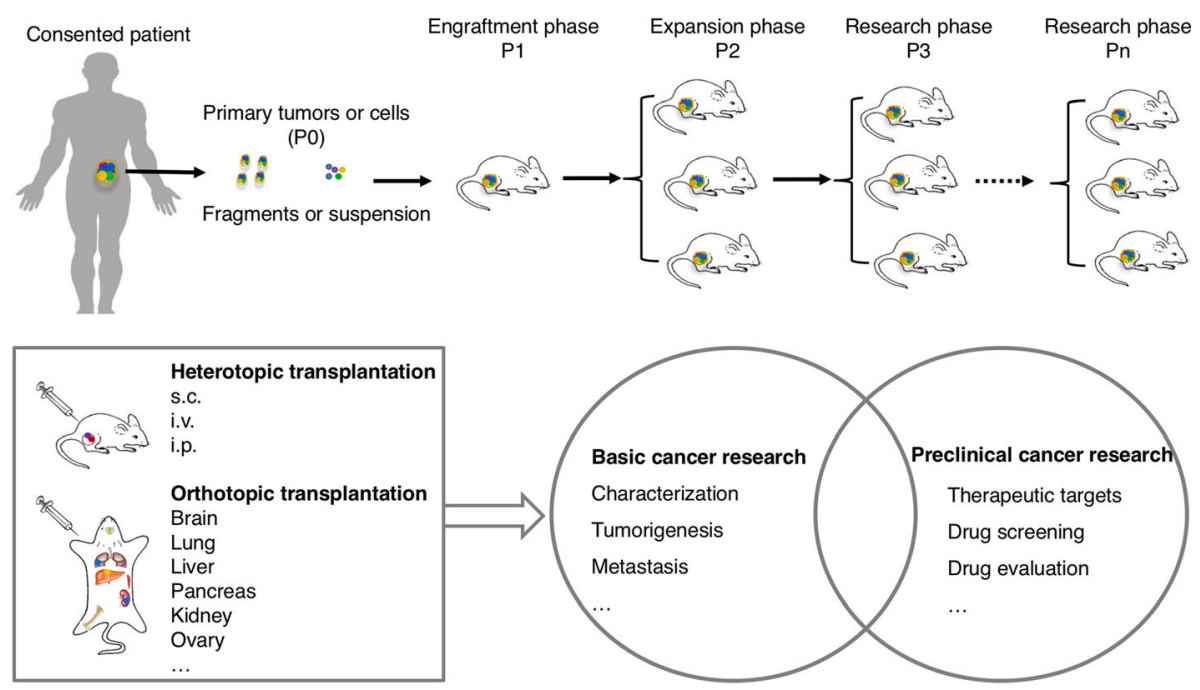

Fig. 1 Overview of the methodology to establish PDX models and their uses in cancer research. Tumors from cancer patients $(P 0)$ are fragmented or digested into single-cell suspension and then transplanted (directly or with additives such as Matrigel) into immunodeficient mice (P1) for engraftment. Once grown, the tumors were transplanted into secondary recipients (P2) for tumor expansion. The expanded tumors can then be cryopreserved or transplanted into P3 mice for cancer research of the type of origin. Specifically, tumors can be transplanted into the sites other than that the tumors are derived, called heterotopic transplantation or into the corresponding sites of the tumors like the brain [39, 97], lung [130], liver [12], pancreas [131, 132], kidney [26], and ovary [11], which is called orthotopic transplantation. The successfully established PDX models are to be used in cancer research, which consists of two, basic and preclinical, arms. Basic and preclinical cancer research in PDX models are connected with each other, as basic research can identify therapeutic targets or strategies for preclinical tests and preclinical research can generate new basic questions

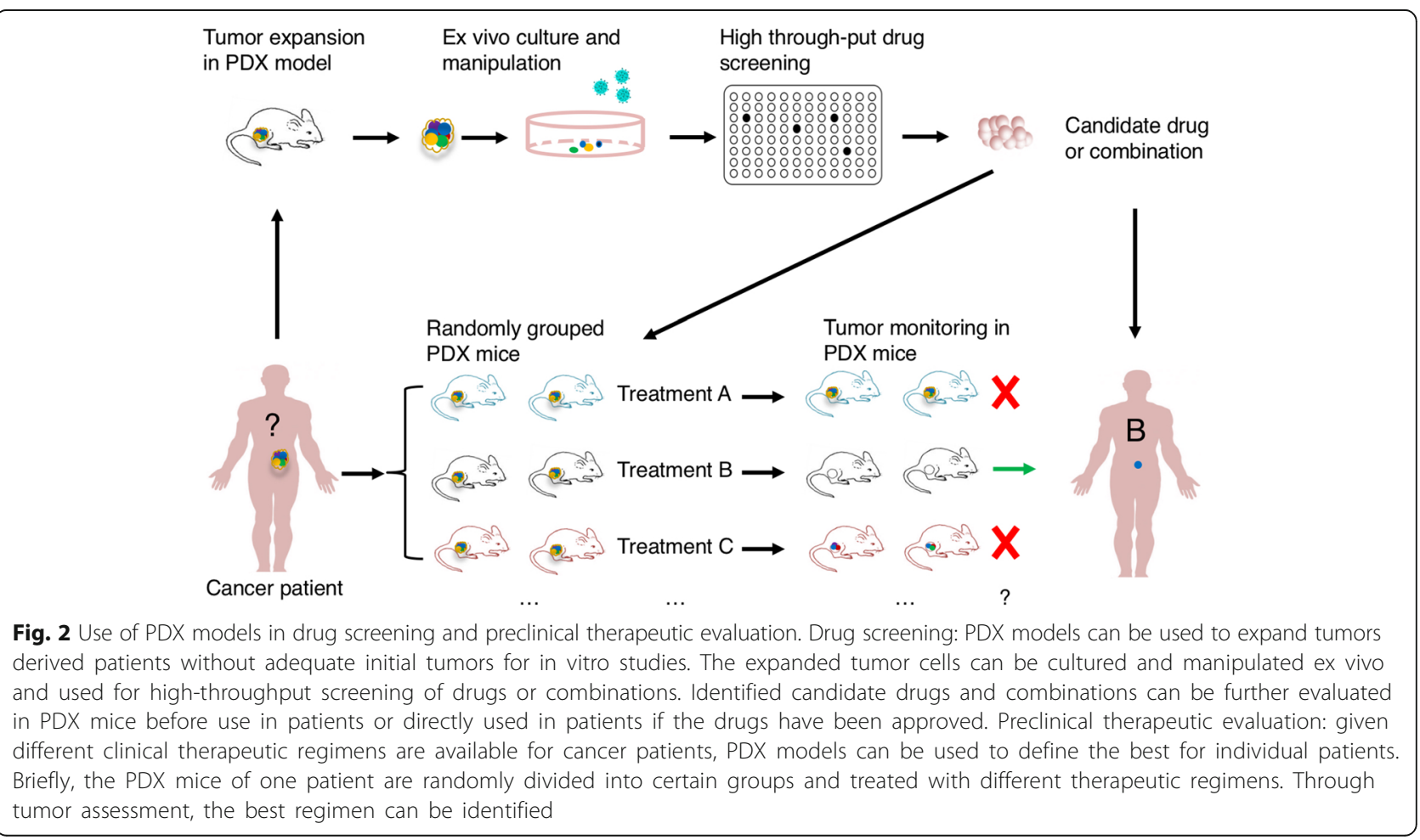




\section{Methodology to establish PDX models Immunodeficient mice}

Immunodeficient mice engrafted with human immune systems provide powerful models for the study of human immunobiology in vivo, and PDX models with these humanized mice are critical tools for studying the interaction between human immunity and various cancers. In order to establish a PDX model, we need a highly immunodeficient mouse strain. Several types of immunodeficient mice can be used to establish xenograft models: athymic nude mice, SCID, NOD-SCID, and recombination-activating gene 2 (Rag2)-knockout mice [14]. However, these strains are usually used to establish cancer cell line xenograft models. Primary cancerous cells or tissues require higher immunodeficiency for efficient engraftment in mice. NOD/SCID mice with IL2rg mutations, such as NOD.Cg-Prkdc ${ }^{\text {scid }} I l 2 r g^{\text {tm } 1 \text { Wjl }}$ (NSG) [15] and NODShi.Cg-Prkd $c^{\text {scid }} I l 2 r g^{\text {tm1Sug }}$ (NOG) mice [16], are with enhanced immunodeficiency and able to engraft almost all types of human cancers [17-20]. We generated a strain of NOD/SCID/IL2rg -I- (NSI) mice, which exhibit severe immunodeficiency, lacking $\mathrm{T}, \mathrm{B}$, and NK cells, and used these mice in studies of both leukemia and solid tumors [21-25]. As the number of immunodeficient strains increases, the choice of mouse strains for cancer research matters. We developed a method to quantitatively evaluate the immunodeficiency of various strains of mice, through the tumor engraftment index (TEI) [21]. Recently, we also derived a nude train of NOD/SCID/IL2 $\mathrm{rg}^{-/-}$mice, called NSIN, by deleting foxn1 with CRISPR/Cas9 system. The nude NSIN mice showed even higher immunodeficiency than NSI mice by TEI and can be more suitable for studies of tumors with poor engraftment efficiency (data unpublished).

\section{Primary tumor samples}

For the first implantation, patient-derived tumors may be implanted into immunodeficient mice in the form of small tumor fragments or cell suspensions derived from blood of patients or from digestion of tumors into single-cell suspensions. Principal determinants of successful tumor engraftment into immunodeficient mice are the viability and sterility of the human tumor [26]. Cancer cells or tissues can be mixed with basement membrane matrix proteins (Matrigel) before injected into recipient animals, which enables the growth of tumors with greater efficiency of take and growth [27], without loss of the primary tumor phenotype [28]. Tumor cells can also be co-injected with additional cell types, such as fibroblasts, stromal cells, and endothelial cells, according to experimental objectives.

\section{Heterotopic vs orthotopic implantation}

Cancerous cells or tissues can be implanted heterotopically or orthotopically and monitored for tumor formation (Fig. 1). In contrast to orthotopic implantation, heterotopic implantation has advantages including easy methods of cell implantation, accurate monitoring of tumor size. Subcutaneous and intravenous PDX models, for solid tumors and leukemia, respectively, are most widely used in cancer research. Orthotopic implantation is more technically challenging and time-consuming and often requires ultrasound examinations or exploratory laparotomies to confirm the presence of tumors inside; however, the advantage is that the external milieu is more closely preserved in orthotopic tumors and theoretically better approximates the "natural" setting of human tumors. Orthotopic implantation can increase the incidence of metastases during xenograft growth and should be considered when tumor metastasis is the investigation subject [29]. To improve the engraftment efficiencies of inadequate quantities of patient-derived tumors, it is favorable to do the initial subcutaneous implantation of patient-derived tumors into F1 mice. Once grown, the tumor may then be digested and orthotopically transplanted into subsequent generations of mice.

\section{Induced pluripotent stem cells (iPSC)-derived PDX models}

Since many patients' primary tumors cannot engraft directly in immunodeficient mice, other methods are needed to establish PDX models for these patients. Primary tumor cells can be reprogrammed to iPSC and then differentiated into the cell type of origin, which then can be used to establish PDX models. PDX models derived through an intermediate iPSC stage could be useful in approximately one third of patients whose primary cells cannot undergo PDXs [30]. An advantage of this method is that an intermediate iPSC stage enables the genetic manipulation of the cells in vitro before transplantation to facilitate tracking or study of their effects on tumor growth in vivo.

\section{Next-generation PDX models with humanized mice}

Recent advances in immunotherapies highlight the importance of the immune system in tumor progression and treatment, which require PDX models with human immune system to facilitate the study of immunitycancer interactions and preclinical assessment of cancer immune therapies. To establish human immune systemconditioned PDX models, we first need to generate humanized mice (also known as human hematolymphoid chimeric mice or human immune system models). One method for the generation of humanized mice involves the transplantation of total peripheral 
blood or tumor-infiltrating lymphocytes (TILs) into immunodeficient mice. These procedures are known to cause severe graft versus host disease (GVHD) 2-5 weeks after injection [31] and limit the useful investigative time window [32]. Another method is to transplant CD34positive human hematopoietic stem cells (HSCs) or precursor cells isolated from the umbilical cord blood, bone marrow, and peripheral blood, either alone or in combination with additional human immune tissues (e.g., human thymic tissue) into immunodeficient mice [33]. Transplantation with HSCs results in a more complete hematopoietic reconstitution, as HSCs give rise to various lineages of human blood cells in mice. To improve the integrity of engrafted human immune system, genetically modified immunocompromised mouse strains have been generated, such as NOG-GM3, NSGSGM3, and MISTRG [34]. The next-generation PDX models based on genetically and immune cells humanized mice, though expensive, are to be used widely in future cancer research.

\section{PDX models in basic cancer research}

Basic cancer research is to characterize cancer biology and explore mechanisms involved for improved understanding or prediction of cancer. PDX models essentially provide important in vivo and ex vivo evidence to aid basic studies of cancer, including tumor characterization, tumorigenesis, and metastasis.

\section{Characterization of cancer biology}

Provided that PDX models faithfully mimic human cancers, they can be used to delineate the per se molecular, cellular, and sub-clonal characterizations of various types of cancers. In the PDX model of acute lymphoblastic leukemia (ALL), a rare unfavorable ALL subpopulation has been defined which is dormant and treatment resistant and mimics patients' primary cells at minimal residual disease [35]. PDX models of acute myeloid leukemia (AML) were used to study the relationships between clonal architecture and functional heterogeneity, in which subclones showed variable engraftment potential in immunodeficient mice and xenografts were predominantly comprised of a single genetically defined subclone [36]. For solid tumors, intratumoral heterogeneity arises from the evolution of genetically diverse subclones during tumor progression, and PDX models are ideal tools for studying the stability, the proliferation, persistence, chemotherapy tolerance, and the mechanisms involved [37]. PDX models revealed that tumor growth can be driven by a minor cell subpopulation, which enhances the proliferation of all cells within a tumor by overcoming environmental constraints and yet can be outcompeted by faster proliferating competitors, resulting in tumor collapse [38].

\section{Tumorigenesis}

PDX models are frequently used to study the cellular components involved in cancer cell initiation and proliferation. The cancer stem cell (CSC) hypothesis suggests that neoplastic clones are maintained exclusively by a rare fraction of cells with stem cell properties. Xenograft assay identified $\mathrm{CD}_{133^{+}}$human brain tumor initiating cells (TICs) that initiate tumors in vivo, providing insights into human brain tumor pathogenesis, giving strong support for the CSC hypothesis as the basis for many solid tumors [39]. The intrinsic molecular mechanisms of tumorigenesis are usually studied in cancer cell line xenograft (CCLX) models, in which cancer cell lines were genetically modified, to consolidate in vitro studies. For examples, LZAP inhibits, by the evidence from cancer cell line xenografts that decreased LZAP expression promoted, tumor growth and vascularity [40]; knockdown of endogenous PCBP1 enhanced tumorigenesis whereas overexpression of exogenous PCBP1 abrogated tumor formation [41]; Notch- and Hedgehog-dependent TICs were identified in prostate cancer CCLX models [42]; short hairpin RNA (shRNA) targeting long noncoding RNAs (lncRNAs) in castration-resistant prostate cancer cell lines strongly suppressed tumor xenograft growth in vivo [43]. Since in vitro expansion and genetic manipulation of primary tumor cells are difficult, we can use PDX models for tumor cell expansion and molecular targeting (inhibitors or agonists). Musashi (Msi) is a critical element of pancreatic cancer progression, and Msi inhibition blocked the growth of primary patient-derived tumors [44]. The initiation of human neuroendocrine prostate cancer from prostate epithelial cells is driven by N-Myc and activated AKT1, as evidenced by the in vivo transformation in NSG mice of prostate basal epithelial cells overexpressing N-Myc and myrAKT1 [45]. MiRNA-126 stabilizes B-ALL in a proliferative $B$ cell precursor state by targeting cell cycle/apoptosis and p53 response genes and antagonizing miRNA-126 in human B-ALL reduces disease burden in its PDX model [46]. Millions of somatic mutations have been found in cancers through genome sequencing, but the functional impact of most mutations is poorly understood. With the help of PDX models, we can define the impactful mutations that induce tumor formation and/or confer resistance to therapy [47]. The proliferation of human cancer cells can be easily defined or compared through the growth of cancer cells in PDX mice. Human cancer cells in PDX models increase growth rate with time per se without treatment [48]. A method was established for identifying novel cancer targets via negative-selection RNAi screening using a human breast cancer xenograft model at an orthotopic site in the mouse, by which a set of metabolic genes associated with aggressive breast 
cancer and stemness were screened to identify those required for in vivo tumorigenesis [49].

\begin{abstract}
Metastasis
Metastasis is the basis of cancer lethality, of which the mechanisms are not fully understood and interventional strategies not well defined. PDX models are useful in defining cell populations and molecules associated with metastasis. Metastasis-initiating cells (MICs) have been proven critical for cancer metastasis. But it is difficult to identify and isolate adequate numbers of MICs from patients for research. PDX models are depositories of MICs. PDX model of human breast cancer was used to identify and isolate MICs through a highly sensitive fluorescence-activated cell sorting (FACS)-based assay [50]. Circulating tumor cells (CTCs) play a critical role in tumor metastasis and have been identified and isolated from patients with several tumor types. Isolated CTCs have been used to generate PDX models of breast [51], pancreatic [52], and prostate cancers [53]. And these PDX models are ideal for the study of tumorigenecity, phenotypic and genetic characterizations of CTCs [54]. Recently, both CCLX and PDX models were used to assess the effect of blocking the fatty acid receptor CD36 on the metastasis of cancer which revealed CD36 as an anti-metastasis target [55]. Elsewhere, the relationship between metastasis and P53 deficiency was studied in PDX models of triple-negative breast cancer [56].
\end{abstract}

\section{PDX models in preclinical cancer research}

Anti-cancer therapies exert selective pressure on tumor cells that leads to the preferential growth of resistant subpopulations, necessitating the development of novel generations of therapies to treat the evolving cancers. A critical role for PDX models in preclinical research is to identify therapeutic targets, including specific molecules and molecular interactions. Another major role for PDX models is as a guide for the clinical treatment of cancer patients (Fig. 2). The choice of therapeutics is critical for cancer treatment and is dependent on the cancer type and the patient. PDX models provide solutions to the challenges that researchers face in cancer drug research such as positive tumor responses in mouse models but not translating over when the study is implemented in humans.

First, PDX models can help to discriminate the most suitable therapy for cancer patients (Fig. 2). PDX models can be used to identify patients with cancers that are resistant to chemotherapy [57] and define the association between drug resistance and genetic mutations [58]. Second, PDX models can be used to identify and evaluate new anti-cancer therapeutic approaches, including new conventional chemotherapies, surgery, radiation, and also the less common microwave, nanoparticles, genetic therapies. For examples, encapsulating BYL719, a PI3K $\alpha$ inhibitor, into P-selectin-targeted nanoparticles led to specific accumulation of BYL719 in the tumor milieu of PDX model for head and neck squamous cell carcinoma [59]; transdifferentiation-induced neural stem cells which were genetically engineered with optical reporters and tumoricidal gene were evaluated effective in globlastoma PDX models [60]; precise fluorescenceguided surgery (FGS) has the potential to greatly improve outcomes for patients with recalcitrant cancers. During development, the technique was preclinically evaluated in a PDX model of pancreatic cancer, in which cancer and stroma cells were labeled with different colors [61] and a PDX model of colon cancer was also used for FGS with fluorophore-conjugated anti-CEA antibody [62]. The preclinical studies of radiation therapies in PDX models have been reviewed elsewhere [63]; a lung cancer cell line xenograft model has been used for evaluation of microwave hyperthermia therapy [64]; however, PDX models have been rarely reported in the evaluation of microwave hyperthermia therapy. Third, which is the most important, PDX models are useful for preclinical drug tests which can indicate drug safety, efficacy, and dosage. PDX models have been applied to preclinical drug testing in many different types of cancers, including pancreatic cancer [65], non-small cell lung cancer (NSCLC) [66, 67], melanoma [68], breast cancer [69, 70], colon cancer [71], and prostate cancer [72]. PDX model-based oncology drug development in specific cancers has been discussed comprehensively [73].

CCLX models are not adequate for preclinical development of anti-cancer agents because most human cancer cell lines do not accurately reflect human malignant tumors [74]. In contrast, PDX models can better recapitulate each individual patient's cancer pathology. The use of these models for in vivo preclinical investigations would yield results more predictive of subsequent activity in patients. PDX models provide in vivo platforms to study the mechanisms by which anti-tumor agents exert their effects and the cellular and molecular mechanisms of therapy resistance of cancers $[75,76]$. Here, we give a brief summary of preclinical cancer research which uses PDX models to identify and evaluate therapeutic targets, varied kinds of anti-cancer "drugs" and therapeutic approaches. Representative drugs and their targets are shown in Table 1.

\section{Identification of cancer biomarkers}

PDX models in preclinical cancer research is to aid the identification of cancer-specific biomarkers that can be used for diagnosis, prognosis, and therapeutically targeted. Whole-transcriptome profiling of PDX models to identify both tumor- and stromal-specific biomarkers 
Table 1 Representative potential therapeutic drugs and their targets in various types of cancers that have been assessed by xenograft models [133]

\begin{tabular}{|c|c|c|c|c|}
\hline Drug or combination & Target & Cancer type & Mouse & References \\
\hline DEL-22379 & Erk & Colorectal cancer & $\mathrm{NOD} / \mathrm{SCID}$ & [134] \\
\hline CSL362 & CD123 & AML & NSG & {$[135]$} \\
\hline Bicalutamide & Androgen & Prostate cancer & SCID & {$[72]$} \\
\hline FP3 & VEGF & Colon cancer & Nude & {$[71]$} \\
\hline Pyruvinium pamoate & Glutathione & Lymphoma & NOG & {$[116]$} \\
\hline Ponatinib, dovitinib, and BGJ398 & FGFR & Cholangiocarcinoma & NSG & \\
\hline Luteolin & cMet & Gastric cancer & Nude & [95] \\
\hline BKM120 & PI3K inhibitor & Pancreatic adenocarcinoma & NSG & {$[52]$} \\
\hline Erlotinib and gefitinib & EGFR & Chordomas & Nude & {$[86]$} \\
\hline Salmonella A1-R & - & Melanoma & Nude & [104] \\
\hline Salmonella A1-R and doxorubicin & - & Sarcoma & Nude & [103] \\
\hline Trastuzumab & Her2 & $\begin{array}{l}\text { Esophageal squamous cell } \\
\text { carcinoma }\end{array}$ & Nude and SCID & [99] \\
\hline Trastuzumab/cetuximab & Her2/EGFR & Gastric cancer & Nude & [98] \\
\hline Cetuximab/bevacizumab & EGFRNEGF & Colon cancer & Nude & {$[136]$} \\
\hline Cetuximab & EGFR & Lung Adenocarcinoma & NOD/SCID & {$[87]$} \\
\hline AZD5363 & AKT & Gastric cancer & Nude & [88] \\
\hline Brequinar & $\begin{array}{l}\text { Dihydroorotate } \\
\text { dehydrogenase }\end{array}$ & AML & SCID & [137] \\
\hline GSK2879552 & LSD1, lysine demethylase 1 & Small cell lung cancer & Nude & {$[138]$} \\
\hline Anti-CD47 antibody & CD47 & Non-Hodgkin lymphoma & NSG & [114] \\
\hline CHZ868 & JAK2 & B-ALL & NSG & [139] \\
\hline HA15 & Bip & Melanoma & nude & [140] \\
\hline UNC0379 & SETD8 & Neuroblastoma & Nude & [141] \\
\hline PARP inhibitors and $\beta$-lapachone & DNA repair & Pancreatic cancer and NSCLC & NOD/SCID & {$[142]$} \\
\hline MCB-613 & Steroid Receptor Coactivator & Breast cancer (MCF-7) & Nude & {$[143]$} \\
\hline P5091 & USP7 & Multiple myeloma & SCID & {$[144]$} \\
\hline MLN8237 and ABT-199 & Aurora kinase and $\mathrm{BCL}-2$ & Neuroblastoma & SCID & [111] \\
\hline TH287 and TH588 & MTH1 & Melanoma & NOG & [93] \\
\hline Agonists & HIF-2 & Renal cell carcinoma & Nude & {$[145]$} \\
\hline SSR128129E (SSR) & FGFR & $\begin{array}{l}\text { Lewis lung carcinoma } \\
\text { And breast cancer }\end{array}$ & Nude & {$[146]$} \\
\hline $\mathrm{CH} 5424802$ & ALK & NSCLC & SCID or nude & [147] \\
\hline ON01910 & Plk1 & $\begin{array}{l}\text { Liver, breast, and pancreatic } \\
\text { cancers }\end{array}$ & Nude & {$[148]$} \\
\hline Shepherdin & ATP pocket of Hsp90 & Prostate cancer & SCID and beige & [149] \\
\hline PD0325901 & MEK & BRAF mutant cancer & Nude & {$[150]$} \\
\hline Monoclonal antibody & S1P & Multiple cancers & Nude & [151] \\
\hline NSC23766 & Rac & P210-BCR-ABL positive CML & NOD/SCID & {$[152]$} \\
\hline Argyrin A & Proteasome & Colon cancer & Nude & [153] \\
\hline Syk inhibitors & Syk & AML & NOG & {$[154]$} \\
\hline Polyphenylureas & $\begin{array}{l}\text { XIAP, an apoptosis } \\
\text { suppressor }\end{array}$ & Prostate and colon cancers & Nude & {$[155]$} \\
\hline RD162 and MDV3100 & Androgen & Advanced prostate cancer & SCID & {$[156]$} \\
\hline
\end{tabular}


Table 1 Representative potential therapeutic drugs and their targets in various types of cancers that have been assessed by xenograft models [133] (Continued)

\begin{tabular}{|c|c|c|c|c|}
\hline EPI-001 & $\begin{array}{l}\text { Androgen receptor } \\
\text { NTD domain }\end{array}$ & $\begin{array}{l}\text { Castrate-recurrent } \\
\text { prostate cancer }\end{array}$ & $\mathrm{NOD} / \mathrm{SCID}$ & [157] \\
\hline piperlongumine & Stress response to ROS & Multiple cancers & nude & [158] \\
\hline CFI-400945, inhibitor & PLK4 & Multiple cancers & NSG and SCID & [159] \\
\hline BDA-366 & $\mathrm{Bc} 12 \mathrm{BH} 4$ domain & Lung cancer & Nude & [160] \\
\hline ССТ196969, ССТ241161 & pan-RAF and SFKs & Multiple cancers & Nude & [161] \\
\hline SR9243, LXR inverse agonist & LXR & Multiple cancers & Nude & [162] \\
\hline SHP099 & SHP2 & RTK-driven cancer & Nude & [163] \\
\hline Antibody & $\mathrm{RSPO} 3$ & Colorectal cancer & Nude & [164] \\
\hline CB-5083 & AAA ATPase p97 & $\begin{array}{l}\text { Multiple myeloma and } \\
\text { solid tumors }\end{array}$ & $\begin{array}{l}\text { Nude and } \\
\text { SCID-Beige }\end{array}$ & [165] \\
\hline Bl-505 & ICAM-1 & B cell cancer and MM & SCID & [166] \\
\hline MLN4924 & NEDD8-Activating Enzyme & Multiple cancers & SCID & [167] \\
\hline Selinexor (KPT-330) & XPO1 & AML & NSG & [168] \\
\hline $\begin{array}{l}\text { Matrix metalloproteinase inhibitor } \\
\text { prinomastat (AG3340) }\end{array}$ & Matrix metalloproteinase & $\begin{array}{l}\text { Pancreatic ductal } \\
\text { adenocarcinoma }\end{array}$ & SCID & [169] \\
\hline
\end{tabular}

supports drug efficacy studies and compartment-specific biomarker discovery [77]. PDX models have been used to evaluate possible detective agents for the diagnosis of cancers, such as the fluorescently labeled chimeric antiCEA antibody in the detection of colon cancer [78]. The prognostic value of stem cell markers in cancers such as hepatocellular carcinoma (HCC) [79] has been evaluated in PDX models. For cancers such as bladder cancer, PDX models are useful both for the discovery of novel molecular targets and predictive biomarkers and for determining the risk of treatment failure [80]. Generation of paired chemonaive and chemoresistant small cell lung cancer (SCLC) PDX models led to the finding that EZH2 promotes chemoresistance by epigenetically silencing SLFN11, and EZH2 inhibition prevents acquisition of chemoresistance and improves chemotherapeutic efficacy in SCLC [81]. NEK2 represents a strong predictor for drug resistance and poor prognosis in cancer, in that targeting NEK2 by NEK2 shRNA overcame drug resistance and induced apoptosis in vitro and in a myeloma PDX model [82]. The long non-coding RNA gene SAMMSON can be targeted to sensitize melanoma to MAPK-targeting therapeutics both in vitro and in PDX models [83]. The IGF-1 receptor is universally expressed in various cancers, which can be therapeutically targeted, as exemplified by an orthotopic PDX model of multiple myeloma [84].

\section{Identification and evaluation of potential drugs Chemicals}

Conventional chemotherapy is still the mainstay treatment modality for various cancers, and PDX models are valuable tools for the evaluation of chemical drugs in vivo. PDX models have been used to evaluate dozens of small-molecule compounds, mainly kinase inhibitors, in various cancers. Kinase inhibitors have been tested in PDX models for cholangiocarcinoma [85], chordoma [86], NSCLC [87], gastric cancer [88], etc. VEGF blocker FP3 inhibited gastric cancer through an antiangiogenic mechanism in a PDX model [89]. CXCR4 is critical to T-ALL cell leukemogenicity and required for T-ALL migration, homing, and niche positioning [90]. And targeting CXCR4 with small-molecule antagonists reduces tumor growth in murine T-ALL and T-ALL PDX models [91]. Inhibition of the MDM2-p53 interaction suppressed tumor growth in PDX models for NSCLC [92]. Inhibition of MTH1 selectively causes incorporation of oxidized dNTPs in cancer cells, leading to DNA damage, cytotoxicity, and therapeutic responses in patient-derived mouse xenografts [93]. Gesterone receptor antagonists show antiproliferative and proapoptotic activities in breast cancer PDX models [94]. Luteolin inhibits tumor growth in cMet-overexpressing PDX models of gastric cancer [95]. The compound trabectedin modulates gene and microRNA expression and various signaling pathways in PDX models [96]. PF-06463922, a potent and brainpenetrant ALK/ROS1 inhibitor, displayed superior potency against all known clinically acquired ALK mutations and inhibited regression of EML4-ALK-driven brain metastases and prolonged survival of PDX mice [97].

\section{Antibodies}

Moreover, PDX models are valuable tools for the tests of novel antibodies before clinical application. Antibodybased therapies have been widely used in the clinical treatment of cancer patients, and PDX models have been 
used to test the use of antibodies for the treatment of various cancers $[98,99]$. Especially, immune checkpoint blockade therapy (ICBT), which blocks PD-1, PD-L1, or CTLA4 with antibodies, has elicited a remarkable clinical response in certain cancer patients. We recently evaluated new PD-1/PD-L1 antibodies in NSCLC PDX models established in humanized NSI mice reconstituted with human HSC or blood cells (unpublished). Nevertheless, intrinsic resistance to immune checkpoint inhibitors remains a daunting challenge [100]. PDX models can be used to evaluate treatments targeting specific resistance mechanisms to sensitize ICBT-resistant tumors. As for other antibodies, NSCLC PDX models with genetic aberrations within EGFR, KRAS, and FGFR1 were used to evaluate the range of responses to Gefitinib, which were shown in vivo to be consistent with the results of clinical trials [66]. In a human bladder cancer PDX model, bladder cancer stem cells (CSCs) actively contribute to therapeutic resistance, which can be abrogated by a PGE2-neutralizing antibody and celecoxib drug-mediated blockade of PGE2 signaling [101].

\section{Anti-cancer microorganisms}

PDX models are valuable tools for the careful assessment of attenuated microorganisms in cancer treatment. Salmonella typhimurium A1-R, a facultative anaerobe that can grow in the oxic viable region of tumors and in necrotic regions, has shown efficacy against osteosarcoma [102], soft-tissue sarcoma [103], and melanoma [104] in orthotopic PDX models. And the oncolytic viruses are also promising for cancer treatment. The attenuated vesicular stomatitis strains, AV1 and AV2, were tested in a xenograft model of ovarian cancer, which effected complete and durable cures in the majority of treated animals when delivered systemically [105]. Oncolytic virus Delta24-RGD [106] and measles virus strains [107] have been tested in PDX models for glioblastoma.

\section{Drug combinations}

Targeted cancer therapies often lead to resistance, which can be suppressed through combination drug therapies. Combinatory targeting of two or more onco-signaling pathways is a promising strategy for cancer therapy. We recently used B-ALL PDX models to evaluate the anti-BALL efficacy of the combination of disulfiram and copper [108]. PDX models are useful for defining the optimal target combinations which avoid therapy resistance, as has been done in the glioblastoma PDX model through single-cell phosphoproteomics [109]. CDK4/6 inhibitors resensitize PDX tumors to HER2-targeted therapies and delay tumor recurrence [110]. Combination treatment with the Aurora kinase A inhibitor MLN8237 and ABT-199 is synergistic in PDX models of MYCN-amplified neuroblastomas [111]. Combined
CDK4/6-PI3K inhibition overcomes intrinsic and adaptive resistance leading to tumor regressions in PIK3CA mutant breast cancer PDXs [112]. BRAF (V600E) mutant colon cancers may benefit from a combination therapy consisting of BRAF and EGFR inhibitors; EGFR and BRAF (V600E) inhibitors synergize to induce apoptosis of colorectal cells and to suppress colorectal tumor growth in a xenograft model [113]. Anti-CD47 antibody synergized with rituximab, by promoting phagocytosis, to eliminate lymphoma in both disseminated and localized non-Hodgkin lymphoma (NHL) xenograft models [114].

\section{High-throughput drug screening and assessment}

A major issue in cancer drug development is the low success rate of new agents. Many compounds advance to large phase III studies, which consume considerable resources, but eventually fail because of low efficacy. These poor results arise partly because conventional preclinical models to screen new agents for clinical development have poor predictive value [115]. Furthermore, new drugs are tested in patients without selection and response monitoring through appropriate biomarkers. In this regard, the availability of PDX models with high predictive value is of major interest. The ex vivo cultured PDX tumor cells can be used for the in vitro highthroughput screening of anti-cancer drugs (Fig. 2) [116]. PDX models theoretically can provide unlimited sources of human tumor cells for ex vivo high-throughput drug assessment. A large biobank of breast cancer PDXs, which preserves morphological and molecular characteristics and intra-tumor genomic clonal architecture of the originating tumors, has been generated and used for high-throughput drug assessment in PDX-derived tumor cells in vitro [117]. The Public Repository of Xenografts (PRoXe) is a publicly available repository of well-characterized leukemia and lymphoma PDXs, which can be used to characterize drug efficacy and generate transcriptional, functional, and proteomic biomarkers in both treatment-naive and relapsed/refractory disease, and randomized phase II-like studies with PRoXe are applicable to a range of therapeutic agents, especially those that act through cancer cell-intrinsic mechanisms [118]. PDX models are also useful for assessment of drugs screened from high-throughput computational design. A novel computational design approach yields multivalent pan-RAS inhibitors and PDX models were used to confirm the efficacy of the identified small-molecule compound binding to KRAS ${ }^{\mathrm{G} 12 \mathrm{D}}$ [119]. Another computationally designed protein BINDI, binding with BHRF1 of Epstein-Barr virus, suppressed tumor growth and extended survival in a PDX model of EBV-positive human lymphoma [120]. 


\section{CAR T cell immunotherapies}

Adoptive transfer of chimeric antigen receptor (CAR) $\mathrm{T}$ cells has shown great promise in treating cancers, especially in B cell leukemia with CAR T cells targeting CD19. PDX models are frequently used for preclinical studies of chimeric antigen receptor (CAR) $\mathrm{T}$ cells [121-123]. Novel designs of CARs have been frequently evaluated in PDX models. The in vivo model with NSG mice was critical to demonstrate that targeting an anti-CD19 CAR to the TRAC locus with CRISPR/Cas9 enhances tumor rejection, a strategy averting antigen-stimulated differentiation and exhaustion [124]. The "On-switch" CARs that enable smallmolecule control over CAR T cell therapeutic function as to timing, location, and dosage of $\mathrm{T}$ cell activity, thereby mitigating toxicity [125]. Loss of HVEM, which disrupts HVEM-BTLA inhibitory interaction, leads to cell-autonomous activation of $\mathrm{B}$ cell proliferation and promotes lymphoma development. So, the anti-CD19 CAR T cells producing HVEM were tested and showed improved anti-lymphoma efficacy in the PDX model [126]. The CAR T cell immunotherapies have not generated satisfactory results in almost all types of solid tumors. PDX models for solid tumors will play essential roles in future studies to promote efficacies of CAR $\mathrm{T}$ cells against solid tumors.

In summary, PDX models facilitate the discovery and testing of various therapeutic regimens including smallmolecule compounds, antibodies, microorganisms, and cytotoxic cells.

\section{Discussion}

PDX models can provide in vivo evidences to support in vitro findings, and data from PDX models may lead to new discoveries or hypotheses which can be further investigated by research in vitro. The use of these xenograft models to study human tumor biology and drug screening is, however, limited by several factors, including the replacement of human stromal components (such as cancer-associated fibroblasts, endothelial cells, immune and inflammatory cells) by murine elements, the lack of a functional immune system, and the lack of interactions between human stromal cells and the immune system. The development of PDX models that account for interactions between tumor, stromal, vascular, and immune cells is essential to produce a tumor microenvironment more representative of the human host. PDX models in humanized xenochimeric mice, or XactMice, engrafted with human HSPCs before tumor engraftment expressed the chemical stimuli necessary to give rise to stromal and immune cells that recreated the original tumor microenvironment observed clinically [127]; nonetheless, better PDX models are still needed to simulate real cancer-stromal interactions in patients.
Furthermore, new approaches to optimizing cancer drug development are required to fully achieve the goal of individualized, precision cancer therapy, and improved preclinical models that more closely reflect the genomic complexity of human cancers are needed.

Recent studies using single-cell sequencing suggest that in some PDX models, only a limited number of clones propagate in mice, indicating a selection process [128]. The identification of lymphocytes recognizing tumor-specific mutant neoantigens represents a major step toward the future eradication of heterogeneous cancers. Only recently reported was the identification of neoantigen-specific lymphocytes in the peripheral blood of melanoma patients [129]. However, the routine detection of lymphocytes that target neoantigens is currently limited to $\mathrm{T}$ cells isolated directly from cancer patients, which are often not available. This limitation might be overcome using PDX models produced by engrafting an autologous immune system. With genetically humanized immunodeficient mice which can engraft a more integrate human immune system, we will be able to upgrade the translational research on cancers as well as on other diseases including infectious diseases and autoimmune diseases.

\section{Conclusions}

PDX models are increasingly used in translational cancer research. These models are useful for the study of cancer biology, biomarker development, drug screening, and the preclinical evaluation of personalized medicine strategies. This review provides a timely overview of the key roles of PDX models in both basic and preclinical cancer research and a detailed discussion of major hurdles in the field.

\section{Abbreviations}

CTCs: Circulating tumor cells; FGS: Precise fluorescence-guided surgery; HCC: Hepatocellular carcinoma; NSCLC: Non-small cell lung cancer; PDX: Patient-derived xenograft

\section{Acknowledgements}

Not applicable.

\section{Funding}

This study was supported by the National Natural Science Foundation of China (81522002), the Strategic Priority Research Program of the Chinese Academy of Sciences (XDB19030205), the Natural Science Fund for Distinguished Young Scholars of Guangdong Province (2014A030306028), the Guangdong Provincial Applied Science and Technology Research\& Development Program (2016B020237006), the Guangdong Provincial Outstanding Young Scholars Award (2014TQ01R068), the Frontier and Key Technology Innovation special grant from the Department of Science and Technology of Guangdong province, (2015B020227003, 2014B020225005, 2016B030229006), the Guangdong Provincial Research and Commercialization Program (Grant No. 2014B090901044), and the Guangzhou Science Technology and Innovation Commission Project (201504010016). 


\section{Availability of data and materials}

The data supporting the conclusions of this article are included within the article.

\section{Authors' contributions}

$Y L, X W, L Q$ and $L C$ drafted and revised the manuscript, $S L$ drew pictures in the figures and PL designed the structure of the manuscript. All authors read and approved the final manuscript.

\section{Competing interests}

The authors declare that they have no competing interests.

\section{Consent for publication}

Consent to publish has been obtained from the participants.

\section{Ethics approval}

All experimental protocols (SYXK(Yue)2015-0063) were performed in accordance with the instruction guidelines from the China Council on Animal Care and approved by the guidelines of the Ethics Committee of Animal Experiments at Guangzhou Institutes of Biomedicine and Health (GIBH).

\section{Publisher's Note}

Springer Nature remains neutral with regard to jurisdictional claims in published maps and institutional affiliations.

\begin{abstract}
Author details
${ }^{1}$ Key Laboratory of Regenerative Biology, South China Institute for Stem Cell Biology and Regenerative Medicine, Guangzhou Institutes of Biomedicine and Health, Chinese Academy of Sciences, Guangzhou 510530, China. ${ }^{2}$ Guangdong Provincial Key Laboratory of Stem Cell and Regenerative Medicine, South China Institute for Stem Cell Biology and Regenerative Medicine, Guangzhou Institutes of Biomedicine and Health, Chinese Academy of Sciences, Guangzhou 510530, China. ${ }^{3}$ Department of Abdominal Surgery, Affiliated Cancer Hospital \& Institute of Guangzhou Medical University of Guangzhou Medical University, Guangzhou Medical University, Guangzhou, Guangdong 510095, China.
\end{abstract}

Received: 15 March 2017 Accepted: 22 April 2017

Published online: 12 May 2017

\section{References}

1. Singer DS, Jacks T, Jaffee E, A U.S. "Cancer Moonshot" to accelerate cancer research. Science. 2016;353:1105-6.

2. Siegel RL, Miller KD, Jemal A: Cancer statistics, 2017. CA Cancer J Clin. 2017;67:7-30

3. Chen C, He M, Zhu Y, Shi L, Wang X. Five critical elements to ensure the precision medicine. Cancer Metastasis Rev. 2015;34:313-8.

4. Hoffman RM. Patient-derived orthotopic xenografts: better mimic of metastasis than subcutaneous xenografts. Nat Rev Cancer. 2015;15:451-2.

5. Durig J, Ebeling P, Grabellus F, Sorg UR, Mollmann M, Schutt P, Gothert J, Sellmann L, Seeber S, Flasshove M, et al. A novel nonobese diabetic/severe combined immunodeficient xenograft model for chronic lymphocytic leukemia reflects important clinical characteristics of the disease. Cancer Res. 2007;67:8653-61.

6. Chapuy B, Cheng H, Watahiki A, Ducar MD, Tan Y, Chen L, Roemer MG, Ouyang J, Christie AL, Zhang L, et al. Diffuse large B-cell lymphoma patient-derived xenograft models capture the molecular and biological heterogeneity of the disease. Blood. 2016;127:2203-13.

7. Tignanelli CJ, Herrera Loeza SG, Yeh JJ. KRAS and PIK3CA mutation frequencies in patient-derived xenograft models of pancreatic and colorectal cancer are reflective of patient tumors and stable across passages. Am Surg. 2014;80:873-7.

8. Seol HS, Kang HJ, Lee SI, Kim NE, Kim TI, Chun SM, Kim TW, Yu CS, Suh YA, Singh SR, et al. Development and characterization of a colon PDX model that reproduces drug responsiveness and the mutation profiles of its original tumor. Cancer Lett. 2014;345:56-64.

9. Zhu Y, Tian T, Li Z, Tang Z, Wang L, Wu J, Li Y, Dong B, Li Y, Li N, et al. Establishment and characterization of patient-derived tumor xenograft using gastroscopic biopsies in gastric cancer. Sci Rep. 2015;5:8542.

10. Zhang T, Zhang L, Fan S, Zhang M, Fu H, Liu Y, Yin X, Chen H, Xie L, Zhang J, et al. Patient-derived gastric carcinoma xenograft mouse models faithfully represent human tumor molecular diversity. PLoS One. 2015;10:e0134493.
11. Dong R, Qiang W, Guo H, Xu X, Kim JJ, Mazar A, Kong B, Wei JJ. Histologic and molecular analysis of patient derived xenografts of high-grade serous ovarian carcinoma. J Hematol Oncol. 2016;9:92.

12. Cavalloni G, Peraldo-Neia C, Sassi F, Chiorino G, Sarotto I, Aglietta M, Leone F. Establishment of a patient-derived intrahepatic cholangiocarcinoma xenograft model with KRAS mutation. BMC Cancer. 2016;16:90.

13. Kuracha MR, Thomas P, Loggie BW, Govindarajan V. Patient-derived xenograft mouse models of pseudomyxoma peritonei recapitulate the human inflammatory tumor microenvironment. Cancer Med. 2016;5:711-9.

14. Morton CL, Houghton PJ. Establishment of human tumor xenografts in immunodeficient mice. Nat Protoc. 2007;2:247-50.

15. Shultz LD, Lyons BL, Burzenski LM, Gott B, Chen X, Chaleff S, Kotb M, Gillies SD, King M, Mangada J, et al. Human lymphoid and myeloid cell development in NOD/LtSz-scid IL2R gamma null mice engrafted with mobilized human hemopoietic stem cells. J Immunol. 2005;174:6477-89.

16. Ito M, Hiramatsu H, Kobayashi K, Suzue K, Kawahata M, Hioki K, Ueyama Y, Koyanagi Y, Sugamura K, Tsuji K, et al. NOD/SCID/gamma(c)(null) mouse: an excellent recipient mouse model for engraftment of human cells. Blood. 2002;100:3175-82

17. Ishikawa F, Livingston AG, Wingard JR, Nishikawa S, Ogawa M. An assay for long-term engrafting human hematopoietic cells based on newborn NOD/ SCID/beta2-microglobulin(null) mice. Exp Hematol. 2002;30:488-94.

18. Hiramatsu H, Nishikomori R, Heike $T$, Ito M, Kobayashi K, Katamura K, Nakahata T. Complete reconstitution of human lymphocytes from cord blood CD34+ cells using the NOD/SCID/gammacnull mice model. Blood. 2003;102:873-80.

19. Agliano A, Martin-Padura I, Mancuso P, Marighetti P, Rabascio C, Pruneri G, Shultz LD, Bertolini F. Human acute leukemia cells injected in NOD/LtSzscid/IL-2Rgamma null mice generate a faster and more efficient disease compared to other NOD/scid-related strains. Int J Cancer. 2008;123:2222-7.

20. Covassin L, Jangalwe S, Jouvet N, Laning J, Burzenski L, Shultz LD, Brehm MA. Human immune system development and survival of non-obese diabetic (NOD)-scid IL2rgamma(null) (NSG) mice engrafted with human thymus and autologous haematopoietic stem cells. Clin Exp Immunol. 2013;174:372-88.

21. Ye W, Jiang Z, Li GX, Xiao Y, Lin S, Lai Y, Wang S, Li B, Jia B, Li Y, et al. Quantitative evaluation of the immunodeficiency of a mouse strain by tumor engraftments. J Hematol Oncol. 2015;8:59.

22. Xiao $Y$, Jiang $Z$, Li Y, Ye W, Jia B, Zhang $M, X u Y, W u ~ D$, Lai $L$, Chen $Y$, et al. ANGPTL7 regulates the expansion and repopulation of human hematopoietic stem and progenitor cells. Haematologica. 2015;100:585-94.

23. Jiang Z, Deng M, Wei X, Ye W, Xiao Y, Lin S, Wang S, Li B, Liu X, Zhang G, et al. Heterogeneity of CD34 and CD38 expression in acute B lymphoblastic leukemia cells is reversible and not hierarchically organized. J Hematol Oncol. 2016;9:94.

24. Ye W, Jiang Z, Lu X, Ren X, Deng M, Lin S, Xiao Y, Lin S, Wang S, Li B, et al.: GZD824 suppresses the growth of human B cell precursor acute lymphoblastic leukemia cells by inhibiting the SRC kinase and PI3K/ AKT pathways. Oncotarget. 2016.

25. Jiang Z, Jiang X, Chen S, Lai Y, Wei X, Li B, Lin S, Wang S, Wu Q, Liang Q, et al. Anti-GPC3-CAR T cells suppress the growth of tumor cells in patientderived xenografts of hepatocellular carcinoma. Front Immunol. 2016;7:690.

26. Pavia-Jimenez A, Tcheuyap VT, Brugarolas J. Establishing a human renal cell carcinoma tumorgraft platform for preclinical drug testing. Nat Protoc. 2014; 9:1848-59.

27. Gock M, Kuhn F, Mullins CS, Krohn M, Prall F, Klar E, Linnebacher M. Tumor take rate optimization for colorectal carcinoma patient-derived xenograft models. Biomed Res Int. 2016;2016:1715053.

28. Alkema NG, Tomar T, Duiker EW, Jan Meersma G, Klip H, van der Zee AG, Wisman GB, de Jong S. Biobanking of patient and patient-derived xenograft ovarian tumour tissue: efficient preservation with low and high fetal calf serum based methods. Sci Rep. 2015;5:14495.

29. Fu X, Guadagni F, Hoffman RM. A metastatic nude-mouse model of human pancreatic cancer constructed orthotopically with histologically intact patient specimens. Proc Natl Acad Sci U S A. 1992;89:5645-9.

30. Papapetrou EP. Patient-derived induced pluripotent stem cells in cancer research and precision oncology. Nat Med. 2016;22:1392-401.

31. King MA, Covassin L, Brehm MA, Racki W, Pearson T, Leif J, Laning J, Fodor W, Foreman O, Burzenski L, et al. Human peripheral blood leucocyte nonobese diabetic-severe combined immunodeficiency interleukin-2 receptor 
gamma chain gene mouse model of xenogeneic graft-versus-host-like disease and the role of host major histocompatibility complex. Clin Exp Immunol. 2009;157:104-18.

32. Holzapfel BM, Wagner F, Thibaudeau L, Levesque JP, Hutmacher DW. Concise review: humanized models of tumor immunology in the $21 \mathrm{st}$ century: convergence of cancer research and tissue engineering. Stem Cells. 2015:33:1696-704

33. Drake $A C$, Chen $Q$, Chen J. Engineering humanized mice for improved hematopoietic reconstitution. Cell Mol Immunol. 2012;9:215-24.

34. Byrne AT, Alferez DG, Amant F, Annibali D, Arribas J, Biankin AV, Bruna A, Budinska E, Caldas C, Chang DK, et al. Interrogating open issues in cancer precision medicine with patient-derived xenografts. Nat Rev Cancer. 2017; 17:254-68.

35. Ebinger S, Ozdemir EZ, Ziegenhain C, Tiedt S, Castro Alves C, Grunert M, Dworzak M, Lutz C, Turati VA, Enver T, et al. Characterization of rare, dormant, and therapy-resistant cells in acute lymphoblastic leukemia. Cancer Cell. 2016;30:849-62.

36. Klco JM, Spencer DH, Miller CA, Griffith M, Lamprecht TL, O'Laughlin M, Fronick C, Magrini V, Demeter RT, Fulton RS, et al. Functional heterogeneity of genetically defined subclones in acute myeloid leukemia. Cancer Cell. 2014:25:379-92

37. Kreso A, O'Brien CA, van Galen P, Gan OI, Notta F, Brown AM, Ng K, Ma J, Wienholds E, Dunant C, et al. Variable clonal repopulation dynamics influence chemotherapy response in colorectal cancer. Science. 2013;339:543-8.

38. Marusyk A, Tabassum DP, Altrock PM, Almendro V, Michor F, Polyak K. Non-cell-autonomous driving of tumour growth supports sub-clonal heterogeneity. Nature. 2014;514:54-8.

39. Singh SK, Hawkins C, Clarke ID, Squire JA, Bayani J, Hide T, Henkelman RM, Cusimano MD, Dirks PB. Identification of human brain tumour initiating cells. Nature. 2004;432:396-401.

40. Wang J, An H, Mayo MW, Baldwin AS, Yarbrough WG. LZAP, a putative tumor suppressor, selectively inhibits NF-kappaB. Cancer Cell. 2007;12:239-51.

41. Wang H, Vardy LA, Tan CP, Loo JM, Guo K, Li J, Lim SG, Zhou J, Chng WJ, $\mathrm{Ng} \mathrm{SB}$, et al. PCBP1 suppresses the translation of metastasis-associated PRL-3 phosphatase. Cancer Cell. 2010;18:52-62.

42. Domingo-Domenech J, Vidal SJ, Rodriguez-Bravo V, Castillo-Martin M, Quinn SA, Rodriguez-Barrueco R, Bonal DM, Charytonowicz E, Gladoun N, de la Iglesia-Vicente J, et al. Suppression of acquired docetaxel resistance in prostate cancer through depletion of notch- and hedgehog-dependent tumor-initiating cells. Cancer Cell. 2012;22:373-88.

43. Yang L, Lin C, Jin C, Yang JC, Tanasa B, Li W, Merkurjev D, Ohgi KA, Meng D, Zhang J, et al. IncRNA-dependent mechanisms of androgen-receptor-regulated gene activation programs. Nature. 2013;500:598-602.

44. Fox RG, Lytle NK, Jaquish DV, Park FD, Ito T, Bajaj J, Koechlein CS, Zimdahl B, Yano $M$, Kopp $J$, et al. Image-based detection and targeting of therapy resistance in pancreatic adenocarcinoma. Nature. 2016;534:407-11.

45. Lee JK, Phillips JW, Smith BA, Park JW, Stoyanova T, McCaffrey EF, Baertsch R, Sokolov A, Meyerowitz JG, Mathis C, et al. N-Myc drives neuroendocrine prostate cancer initiated from human prostate epithelial cells. Cancer Cell. 2016;29:536-47.

46. Nucera S, Giustacchini A, Boccalatte F, Calabria A, Fanciullo C, Plati T, Ranghetti A, Garcia-Manteiga J, Cittaro D, Benedicenti F, et al. miRNA-126 orchestrates an oncogenic program in B cell precursor acute lymphoblastic leukemia. Cancer Cell. 2016;29:905-21.

47. Berger AH, Brooks AN, Wu X, Shrestha Y, Chouinard C, Piccioni F, Bagul M, Kamburov A, Imielinski M, Hogstrom L, et al. High-throughput phenotyping of lung cancer somatic mutations. Cancer Cell. 2016;30:214-28.

48. Pearson AT, Finkel KA, Warner KA, Nor F, Tice D, Martins MD, Jackson TL, Nor JE. Patient-derived xenograft (PDX) tumors increase growth rate with time. Oncotarget. 2016;7:7993-8005

49. Possemato R, Marks KM, Shaul YD, Pacold ME, Kim D, Birsoy K, Sethumadhavan S, Woo HK, Jang HG, Jha AK, et al. Functional genomics reveal that the serine synthesis pathway is essential in breast cancer. Nature. 2011;476:346-50.

50. Lawson DA, Bhakta NR, Kessenbrock K, Prummel KD, Yu Y, Takai K, Zhou A, Eyob H, Balakrishnan S, Wang CY, et al. Single-cell analysis reveals a stem-cell program in human metastatic breast cancer cells. Nature. 2015;526:131-5.

51. Giuliano M, Herrera S, Christiny P, Shaw C, Creighton CJ, Mitchell T, Bhat R, Zhang $X$, Mao S, Dobrolecki LE, et al. Circulating and disseminated tumor cells from breast cancer patient-derived xenograft-bearing mice as a novel model to study metastasis. Breast Cancer Res. 2015;17:3.
52. Torphy RJ, Tignanelli CJ, Kamande JW, Moffitt RA, Herrera Loeza SG, Soper SA, Yeh JJ. Circulating tumor cells as a biomarker of response to treatment in patient-derived xenograft mouse models of pancreatic adenocarcinoma. PLoS One. 2014;9:e89474.

53. Williams ES, Rodriguez-Bravo V, Chippada-Venkata U, De la Iglesia-Vicente J, Gong Y, Galsky M, Oh W, Cordon-Cardo C, Domingo-Domenech J: Generation of prostate cancer patient derived xenograft models from circulating tumor cells. J Vis Exp. 2015:53182.

54. Yu M, Bardia A, Aceto N, Bersani F, Madden MW, Donaldson MC, Desai R, Zhu H, Comaills V, Zheng Z, et al. Cancer therapy. Ex vivo culture of circulating breast tumor cells for individualized testing of drug susceptibility. Science. 2014;345:216-20.

55. Pascual G, Avgustinova A, Mejetta S, Martin M, Castellanos A, Attolini CS, Berenguer A, Prats N, Toll A, Hueto JA, et al. Targeting metastasis-initiating cells through the fatty acid receptor CD36. Nature. 2017;541:41-5.

56. Powell E, Shao J, Yuan Y, Chen HC, Cai S, Echeverria GV, Mistry N, Decker KF, Schlosberg C, Do KA, et al. p53 deficiency linked to B cell translocation gene 2 (BTG2) loss enhances metastatic potential by promoting tumor growth in primary and metastatic sites in patient-derived xenograft (PDX) models of triple-negative breast cancer. Breast Cancer Res. 2016;18:13.

57. Dobbin ZC, Katre AA, Steg AD, Erickson BK, Shah MM, Alvarez RD, Conner MG, Schneider D, Chen D, Landen CN. Using heterogeneity of the patientderived xenograft model to identify the chemoresistant population in ovarian cancer. Oncotarget. 2014;5:8750-64.

58. Lohse I, Borgida A, Cao P, Cheung M, Pintilie M, Bianco T, Holter S, Ibrahimov E, Kumareswaran R, Bristow RG, et al. BRCA1 and BRCA2 mutations sensitize to chemotherapy in patient-derived pancreatic cancer xenografts. Br J Cancer. 2015:113:425-32

59. Mizrachi A, Shamay Y, Shah J, Brook S, Soong J, Rajasekhar VK, Humm JL, Healey JH, Powell SN, Baselga J, et al. Tumour-specific PI3K inhibition via nanoparticle-targeted delivery in head and neck squamous cell carcinoma. Nat Commun. 2017:8:14292.

60. Bago JR, Alfonso-Pecchio A, Okolie O, Dumitru R, Rinkenbaugh A, Baldwin AS, Miller CR, Magness ST, Hingtgen SD. Therapeutically engineered induced neural stem cells are tumour-homing and inhibit progression of glioblastoma. Nat Commun. 2016;7:10593.

61. Yano S, Hiroshima Y, Maawy A, Kishimoto H, Suetsugu A, Miwa S, Toneri M, Yamamoto $\mathrm{M}$, Katz $\mathrm{MH}$, Fleming JB, et al. Color-coding cancer and stromal cells with genetic reporters in a patient-derived orthotopic xenograft (PDOX) model of pancreatic cancer enhances fluorescence-guided surgery. Cancer Gene Ther. 2015;22:344-50.

62. Hiroshima Y, Maawy A, Metildi CA, Zhang Y, Uehara F, Miwa S, Yano S, Sato S, Murakami T, Momiyama M, et al. Successful fluorescence-guided surgery on human colon cancer patient-derived orthotopic xenograft mouse models using a fluorophore-conjugated anti-CEA antibody and a portable imaging system. J Laparoendosc Adv Surg Tech A. 2014;24:241-7.

63. Willey CD, Gilbert AN, Anderson JC, Gillespie GY. Patient-derived xenografts as a model system for radiation research. Semin Radiat Oncol. 2015;25:273-80.

64. Motomura T, Ueda K, Ohtani S, Hansen E, Ji L, Ito K, Saito K, Sugita Y, Nose $Y$. Evaluation of systemic external microwave hyperthermia for treatment of pleural metastasis in orthotopic lung cancer model. Oncol Rep. 2010;24:591-8.

65. Rubio-Viqueira B, Jimeno A, Cusatis G, Zhang X, lacobuzio-Donahue C, Karikari C, Shi C, Danenberg K, Danenberg PV, Kuramochi H, et al. An in vivo platform for translational drug development in pancreatic cancer. Clin Cancer Res. 2006;12:4652-61.

66. Zhang XC, Zhang J, Li M, Huang XS, Yang XN, Zhong WZ, Xie L, Zhang L, Zhou M, Gavine P, et al. Establishment of patient-derived non-small cell lung cancer xenograft models with genetic aberrations within EGFR, KRAS and FGFR1: useful tools for preclinical studies of targeted therapies. J Transl Med. 2013;11:168.

67. Merk J, Rolff J, Becker M, Leschber G, Fichtner I. Patient-derived xenografts of non-small-cell lung cancer: a pre-clinical model to evaluate adjuvant chemotherapy? Eur J Cardiothorac Surg. 2009;36:454-9.

68. Fiebig HH, Schuler J, Bausch N, Hofmann M, Metz T, Korrat A. Gene signatures developed from patient tumor explants grown in nude mice to predict tumor response to 11 cytotoxic drugs. Cancer Genomics Proteomics. 2007;4:197-209.

69. Marangoni E, Vincent-Salomon A, Auger N, Degeorges A, Assayag F, de Cremoux P, de Plater L, Guyader C, De Pinieux G, Judde JG, et al. A new model of patient tumor-derived breast cancer xenografts for preclinical assays. Clin Cancer Res. 2007;13:3989-98. 
70. de Plater L, Lauge A, Guyader C, Poupon MF, Assayag F, de Cremoux P, Vincent-Salomon A, Stoppa-Lyonnet D, Sigal-Zafrani B, Fontaine JJ, et al. Establishment and characterisation of a new breast cancer xenograft obtained from a woman carrying a germline BRCA2 mutation. Br J Cancer. 2010;103:1192-200.

71. Jin K, Li G, Cui B, Zhang J, Lan H, Han N, Xie B, Cao F, He K, Wang H, et al. Assessment of a novel VEGF targeted agent using patient-derived tumor tissue xenograft models of colon carcinoma with lymphatic and hepatic metastases. PLoS One. 2011;6:e28384.

72. Yoshida T, Kinoshita H, Segawa T, Nakamura E, Inoue T, Shimizu Y, Kamoto T, Ogawa O. Antiandrogen bicalutamide promotes tumor growth in a novel androgen-dependent prostate cancer xenograft model derived from a bicalutamide-treated patient. Cancer Res. 2005:65:9611-6.

73. Tentler JJ, Tan AC, Weekes CD, Jimeno A, Leong S, Pitts TM, Arcaroli JJ, Messersmith WA, Eckhardt SG. Patient-derived tumour xenografts as models for oncology drug development. Nat Rev Clin Oncol. 2012;9:338-50.

74. Bousquet $\mathrm{G}$, Janin A. Patient-derived xenograft: an adjuvant technology for the treatment of metastatic disease. Pathobiology. 2016;83:170-6.

75. Ter Brugge $P$, Kristel $P$, van der Burg E, Boon U, de Maaker M, Lips E, Mulder $L$, de Ruiter J, Moutinho C, Gevensleben H, et al. Mechanisms of therapy resistance in patient-derived xenograft models of BRCA1-deficient breast cancer. J Natl Cancer Inst 2016, 108.

76. Krumbach R, Schuler J, Hofmann M, Giesemann T, Fiebig HH, Beckers T. Primary resistance to cetuximab in a panel of patient-derived tumour xenograft models: activation of MET as one mechanism for drug resistance. Eur J Cancer. 2011;47:1231-43.

77. Bradford JR, Wappett M, Beran G, Logie A, Delpuech O, Brown H, Boros J, Camp NJ, McEwen R, Mazzola AM, et al. Whole transcriptome profiling of patient-derived xenograft models as a tool to identify both tumor and stromal specific biomarkers. Oncotarget. 2016;7:20773-87.

78. Metildi CA, Kaushal S, Luiken GA, Talamini MA, Hoffman RM, Bouvet M. Fluorescently labeled chimeric anti-CEA antibody improves detection and resection of human colon cancer in a patient-derived orthotopic xenograft (PDOX) nude mouse model. J Surg Oncol. 2014;109:451-8.

79. Zhao Q, Zhou H, Liu Q, Cao Y, Wang G, Hu A, Ruan L, Wang S, Bo Q, Chen W, et al. Prognostic value of the expression of cancer stem cell-related markers CD133 and CD44 in hepatocellular carcinoma: from patients to patient-derived tumor xenograft models. Oncotarget. 2016;7:47431-43.

80. Skowron KB, Pitroda SP, Namm JP, Balogun O, Beckett MA, Zenner ML, Fayanju O, Huang X, Fernandez C, Zheng W, et al. Basal tumor cell isolation and patient-derived xenograft engraftment identify high-risk clinical bladder cancers. Sci Rep. 2016;6:35854.

81. Gardner EE, Lok BH, Schneeberger VE, Desmeules P, Miles LA, Arnold PK, Ni A, Khodos I, de Stanchina E, Nguyen T, et al. Chemosensitive relapse in small cell lung cancer proceeds through an EZH2-SLFN11 axis. Cancer Cell. 2017;31:286-99.

82. Zhou W, Yang $Y$, Xia J, Wang $H$, Salama ME, Xiong W, Xu H, Shetty $S$, Chen $T$, Zeng $Z$, et al. NEK2 induces drug resistance mainly through activation of efflux drug pumps and is associated with poor prognosis in myeloma and other cancers. Cancer Cell. 2013;23:48-62.

83. Leucci E, Vendramin R, Spinazzi M, Laurette P, Fiers M, Wouters J, Radaelli E, Eyckerman S, Leonelli C, Vanderheyden K, et al. Melanoma addiction to the long non-coding RNA SAMMSON. Nature. 2016;531:518-22.

84. Mitsiades CS, Mitsiades NS, McMullan CJ, Poulaki V, Shringarpure R, Akiyama M, Hideshima T, Chauhan D, Joseph M, Libermann TA, et al. Inhibition of the insulin-like growth factor receptor-1 tyrosine kinase activity as a therapeutic strategy for multiple myeloma, other hematologic malignancies, and solid tumors. Cancer Cell. 2004;5:221-30.

85. Wang $Y$, Ding X, Wang S, Moser CD, Shaleh HM, Mohamed EA, Chaiteerakij R, Allotey LK, Chen G, Miyabe K, et al. Antitumor effect of FGFR inhibitors on a novel cholangiocarcinoma patient derived xenograft mouse model endogenously expressing an FGFR2-CCDC6 fusion protein. Cancer Lett. 2016;380:163-73.

86. Siu IM, Ruzevick J, Zhao Q, Connis N, Jiao Y, Bettegowda C, Xia X, Burger PC, Hann CL, Gallia GL. Erlotinib inhibits growth of a patient-derived chordoma xenograft. PLoS One. 2013;8:e78895.

87. Martin P, Stewart E, Pham NA, Mascaux C, Panchal D, Li M, Kim L, Sakashita S, Wang D, Sykes J, et al. Cetuximab inhibits T790M-mediated resistance to epidermal growth factor receptor tyrosine kinase inhibitor in a lung adenocarcinoma patient-derived xenograft mouse model. Clin Lung Cancer. 2016;17:375-83. e372.
88. Li J, Davies BR, Han S, Zhou M, Bai Y, Zhang J, Xu Y, Tang L, Wang H, Liu YJ, et al. The AKT inhibitor AZD5363 is selectively active in PI3KCA mutant gastric cancer, and sensitizes a patient-derived gastric cancer xenograft model with PTEN loss to Taxotere. J Transl Med. 2013;11:241.

89. Jin K, Lan H, Cao F, Xu Z, Han N, Li G, He K, Teng L. Antitumor effect of FP3 in a patient-derived tumor tissue xenograft model of gastric carcinoma through an antiangiogenic mechanism. Oncol Lett. 2012;3:1052-8.

90. Passaro D, Irigoyen M, Catherinet C, Gachet S, Da Costa De Jesus C, Lasgi C, Tran Quang C, Ghysdael J. CXCR4 is required for leukemia-initiating cell activity in T cell acute lymphoblastic leukemia. Cancer Cell. 2015;27:769-79.

91. Pitt LA, Tikhonova AN, Hu H, Trimarchi T, King B, Gong Y, Sanchez-Martin M, Tsirigos A, Littman DR, Ferrando AA, et al. CXCL12-producing vascular endothelial niches control acute T cell leukemia maintenance. Cancer Cell. 2015;27:755-68.

92. Hai J, Sakashita S, Allo G, Ludkovski O, Ng C, Shepherd FA, Tsao MS. Inhibiting MDM2-p53 interaction suppresses tumor growth in patient-derived non-small cell lung cancer xenograft models. J Thorac Oncol. 2015;10:1172-80.

93. Gad H, Koolmeister T, Jemth AS, Eshtad S, Jacques SA, Strom CE, Svensson LM, Schultz N, Lundback T, Einarsdottir BO, et al. MTH1 inhibition eradicates cancer by preventing sanitation of the dNTP pool. Nature. 2014;508:215-21.

94. Esber N, Cherbonnier C, Resche-Rigon M, Hamze A, Alami M, Fagart J, Loosfelt $H$, Lombes M, Chabbert-Buffet N. Anti-tumoral effects of antiprogestins in a patient-derived breast cancer xenograft model. Horm Cancer. 2016;7:137-47.

95. Lu J, Li G, He K, Jiang W, Xu C, Li Z, Wang H, Wang W, Wang H, Teng X, Teng L. Luteolin exerts a marked antitumor effect in cMet-overexpressing patient-derived tumor xenograft models of gastric cancer. J Transl Med. 2015;13:42.

96. Peraldo Neia C, Cavalloni G, Chiorino G, Ostano P, Aglietta M, Leone F: Gene and microRNA modulation upon trabectedin treatment in a human intrahepatic cholangiocarcinoma paired patient derived xenograft and cell line. Oncotarget 2016.

97. Zou HY, Friboulet L, Kodack DP, Engstrom LD, Li Q, West M, Tang RW, Wang H, Tsaparikos K, Wang J, et al. PF-06463922, an ALK/ROS1 inhibitor, overcomes resistance to first and second generation ALK inhibitors in preclinical models. Cancer Cell. 2015;28:70-81.

98. Wang CJ, Tong PJ, Zhu MY. The combinational therapy of trastuzumab and cetuximab inhibits tumor growth in a patient-derived tumor xenograft model of gastric cancer. Clin Transl Oncol. 2016;18:507-14.

99. Wu X, Zhang J, Zhen R, Lv J, Zheng L, Su X, Zhu G, Gavine PR, Xu S, Lu S, et al. Trastuzumab anti-tumor efficacy in patient-derived esophageal squamous cell carcinoma xenograft (PDECX) mouse models. J Transl Med. 2012;10:180.

100. Zhao X, Subramanian S. Intrinsic resistance of solid tumors to immune checkpoint blockade therapy. Cancer Res. 2017;77:817-22.

101. Kurtova AV, Xiao J, Mo Q, Pazhanisamy S, Krasnow R, Lerner SP, Chen F, Roh TT, Lay E, Ho PL, Chan KS. Blocking PGE2-induced tumour repopulation abrogates bladder cancer chemoresistance. Nature. 2015;517:209-13.

102. Murakami T, Igarashi K, Kawaguchi K, Kiyuna T, Zhang Y, Zhao M, Hiroshima Y, Nelson SD, Dry SM, Li Y, et al. Tumor-targeting Salmonella typhimurium $A 1-R$ regresses an osteosarcoma in a patient-derived xenograft model resistant to a molecular-targeting drug. Oncotarget. 2017;8:8035-42.

103. Murakami T, DeLong J, Eilber FC, Zhao M, Zhang Y, Zhang N, Singh A, Russell T, Deng S, Reynoso J, et al. Tumor-targeting Salmonella typhimurium A1-R in combination with doxorubicin eradicate soft tissue sarcoma in a patientderived orthotopic xenograft (PDOX) model. Oncotarget. 2016;7:12783-90.

104. Yamamoto M, Zhao M, Hiroshima Y, Zhang Y, Shurell E, Eilber FC, Bouvet M, Noda M, Hoffman RM. Efficacy of tumor-targeting Salmonella A1-R on a melanoma patient-derived orthotopic xenograft (PDOX) nude-mouse model. PLoS One. 2016;11:e0160882.

105. Stojdl DF, Lichty BD, TenOever BR, Paterson JM, Power AT, Knowles S, Marius R, Reynard J, Poliquin L, Atkins H, et al. VSV strains with defects in their ability to shutdown innate immunity are potent systemic anti-cancer agents. Cancer Cell. 2003:4:263-75.

106. Berghauser Pont LM, Kleijn A, Kloezeman JJ, van den Bossche W, Kaufmann JK, de Vrij J, Leenstra S, Dirven CM, Lamfers ML. The HDAC inhibitors Scriptaid and LBH589 combined with the oncolytic virus Delta24-RGD exert enhanced anti-tumor efficacy in patient-derived glioblastoma cells. PLoS One. 2015;10:e0127058.

107. Allen C, Opyrchal M, Aderca I, Schroeder MA, Sarkaria JN, Domingo E, Federspiel MJ, Galanis E. Oncolytic measles virus strains have significant antitumor activity against glioma stem cells. Gene Ther. 2013;20:444-9. 
108. Deng M, Jiang Z, Li Y, Zhou Y, Li J, Wang X, Yao Y, Wang W, Li P, Xu B. Effective elimination of adult B-lineage acute lymphoblastic leukemia by disulfiram/copper complex in vitro and in vivo in patient-derived xenograft models. Oncotarget. 2016;7:82200-12.

109. Wei W, Shin YS, Xue M, Matsutani T, Masui K, Yang H, Ikegami S, Gu Y, Herrmann K, Johnson D, et al. Single-cell phosphoproteomics resolves adaptive signaling dynamics and informs targeted combination therapy in glioblastoma. Cancer Cell. 2016;29:563-73.

110. Goel S, Wang Q, Watt AC, Tolaney SM, Dillon DA, Li W, Ramm S, Palmer AC,

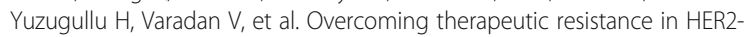
positive breast cancers with CDK4/6 inhibitors. Cancer Cell. 2016;29:255-69.

111. Ham J, Costa C, Sano R, Lochmann TL, Sennott EM, Patel NU, Dastur A, Gomez-Caraballo M, Krytska K, Hata AN, et al. Exploitation of the apoptosisprimed state of MYCN-amplified neuroblastoma to develop a potent and specific targeted therapy combination. Cancer Cell. 2016;29:159-72.

112. Vora SR, Juric D, Kim N, Mino-Kenudson M, Huynh T, Costa C, Lockerman EL, Pollack SF, Liu M, Li X, et al. CDK 4/6 inhibitors sensitize PIK3CA mutant breast cancer to PI3K inhibitors. Cancer Cell. 2014;26:136-49.

113. Prahallad A, Sun C, Huang S, Di Nicolantonio F, Salazar R, Zecchin D, Beijersbergen RL, Bardelli A, Bernards R. Unresponsiveness of colon cancer to BRAF(V600E) inhibition through feedback activation of EGFR. Nature. 2012;483:100-3

114. Chao MP, Alizadeh AA, Tang C, Myklebust JH, Varghese B, Gill S, Jan M, Cha AC, Chan CK, Tan BT, et al. Anti-CD47 antibody synergizes with rituximab to promote phagocytosis and eradicate non-Hodgkin lymphoma. Cell. 2010;142:699-713.

115. Johnson Jl, Decker S, Zaharevitz D, Rubinstein LV, Venditti J, Schepartz S, Kalyandrug S, Christian M, Arbuck S, Hollingshead M, Sausville EA. Relationships between drug activity in $\mathrm{NCl}$ preclinical in vitro and in vivo models and early clinical trials. Br J Cancer. 2001;84:1424-31.

116. Sugimoto K, Hayakawa F, Shimada S, Morishita T, Shimada K, Katakai T, Tomita A, Kiyoi H, Naoe T. Discovery of a drug targeting microenvironmental support for lymphoma cells by screening using patient-derived xenograft cells. Sci Rep. 2015;5:13054

117. Bruna A, Rueda OM, Greenwood W, Batra AS, Callari M, Batra RN, Pogrebniak K, Sandoval J, Cassidy JW, Tufegdzic-Vidakovic A, et al. A Biobank of breast cancer explants with preserved intra-tumor heterogeneity to screen anticancer compounds. Cell. 2016;167:260-74. e222.

118. Townsend EC, Murakami MA, Christodoulou A, Christie AL, Koster J, DeSouza TA, Morgan EA, Kallgren SP, Liu H, Wu SC, et al. The public repository of xenografts enables discovery and randomized phase II-like trials in mice. Cancer Cell. 2016;29:574-86.

119. Welsch ME, Kaplan A, Chambers JM, Stokes ME, Bos PH, Zask A, Zhang Y, Sanchez-Martin M, Badgley MA, Huang CS, et al. Multivalent small-molecule pan-RAS inhibitors. Cell. 2017;168:878-89. e829.

120. Procko E, Berguig GY, Shen BW, Song Y, Frayo S, Convertine AJ, Margineantu D, Booth $\mathrm{G}$, Correia BE, Cheng $\mathrm{Y}$, et al. A computationally designed inhibitor of an Epstein-Barr viral Bcl-2 protein induces apoptosis in infected cells. Cell. 2014:157:1644-56.

121. Posey Jr AD, Schwab RD, Boesteanu AC, Steentoft C, Mandel U, Engels B, Stone JD, Madsen TD, Schreiber K, Haines KM, et al. Engineered CAR T cells targeting the cancer-associated Tn-glycoform of the membrane mucin MUC1 control adenocarcinoma. Immunity. 2016;44:1444-54.

122. Long AH, Haso WM, Shern JF, Wanhainen KM, Murgai M, Ingaramo M, Smith JP, Walker AJ, Kohler ME, Venkateshwara VR, et al. 4-1BB costimulation ameliorates T cell exhaustion induced by tonic signaling of chimeric antigen receptors. Nat Med. 2015:21:581-90.

123. Adusumilli PS, Cherkassky L, Villena-Vargas J, Colovos C, Servais E, Plotkin J, Jones DR, Sadelain M. Regional delivery of mesothelin-targeted CAR T cell therapy generates potent and long-lasting CD4-dependent tumor immunity. Sci Transl Med. 2014;6:261-151.

124. Eyquem J, Mansilla-Soto J, Giavridis T, van der Stegen SJ, Hamieh M Cunanan KM, Odak A, Gonen M, Sadelain M. Targeting a CAR to the TRAC locus with CRISPR/Cas9 enhances tumour rejection. Nature. 2017:543:113-7.

125. Wu CY, Roybal KT, Puchner EM, Onuffer J, Lim WA. Remote control of therapeutic T cells through a small molecule-gated chimeric receptor. Science. 2015;350:aab4077.

126. Boice $M$, Salloum D, Mourcin F, Sanghvi V, Amin R, Oricchio E, Jiang M, Mottok A, Denis-Lagache N, Ciriello G, et al. Loss of the HVEM tumor suppressor in lymphoma and restoration by modified CAR-T cells. Cell. 2016;167:405-18. e413.
127. Morton JJ, Bird G, Keysar SB, Astling DP, Lyons TR, Anderson RT, Glogowska MJ, Estes P, Eagles JR, Le PN, et al. XactMice: humanizing mouse bone marrow enables microenvironment reconstitution in a patient-derived xenograft model of head and neck cancer. Oncogene. 2016;35:290-300.

128. Eirew P, Steif A, Khattra J, Ha G, Yap D, Farahani H, Gelmon K, Chia S, Mar C, Wan $A$, et al. Dynamics of genomic clones in breast cancer patient xenografts at single-cell resolution. Nature. 2015;518:422-6.

129. Gros A, Parkhurst MR, Tran E, Pasetto A, Robbins PF, llyas S, Prickett TD, Gartner JJ, Crystal JS, Roberts IM, et al. Prospective identification of neoantigen-specific lymphocytes in the peripheral blood of melanoma patients. Nat Med. 2016;22:433-8.

130. Wang X, Fu X, Hoffman RM. A new patient-like metastatic model of human lung cancer constructed orthotopically with intact tissue via thoracotomy in immunodeficient mice. Int J Cancer. 1992;51:992-5.

131. Kim MP, Evans DB, Wang H, Abbruzzese JL, Fleming JB, Gallick GE. Generation of orthotopic and heterotopic human pancreatic cancer xenografts in immunodeficient mice. Nat Protoc. 2009:4:1670-80.

132. Pratesi G, Petrangolini G, Tortoreto M, Addis A, Belluco S, Rossini A, Selleri S, Rumio C, Menard S, Balsari A. Therapeutic synergism of gemcitabine and CpG-oligodeoxynucleotides in an orthotopic human pancreatic carcinoma xenograft. Cancer Res. 2005:65:6388-93.

133. Long D, Liu T, Tan L, Shi H, Liang P, Tang S, Wu Q, Yu J, Dou J, Meng X. Multisynergistic platform for tumor therapy by mild microwave irradiationactivated chemotherapy and enhanced ablation. ACS Nano. 2016.

134. Herrero A, Pinto A, Colon-Bolea P, Casar B, Jones M, Agudo-lbanez L, Vidal R, Tenbaum SP, Nuciforo P, Valdizan EM, et al. Small molecule inhibition of ERK dimerization prevents tumorigenesis by RAS-ERK pathway oncogenes. Cancer Cell. 2015;28:170-82.

135. Lee EM, Yee D, Busfield SJ, McManus JF, Cummings N, Vairo G, Wei A, Ramshaw HS, Powell JA, Lopez AF, et al. Efficacy of an Fc-modified antiCD123 antibody (CSL362) combined with chemotherapy in xenograft models of acute myelogenous leukemia in immunodeficient mice. Haematologica. 2015;100:914-26

136. Jin K, Lan H, Cao F, Han N, Xu Z, Li G, He K, Teng L. Differential response to EGFR- and VEGF-targeted therapies in patient-derived tumor tissue xenograft models of colon carcinoma and related metastases. Int J Oncol. 2012;41:583-8.

137. Sykes DB, Kfoury YS, Mercier FE, Wawer MJ, Law JM, Haynes MK, Lewis TA, Schajnovitz A, Jain E, Lee $D$, et al. Inhibition of dihydroorotate dehydrogenase overcomes differentiation blockade in acute myeloid leukemia. Cell. 2016:167:171-86. e115.

138. Mohammad HP, Smitheman KN, Kamat CD, Soong D, Federowicz KE, Van Aller GS, Schneck JL, Carson JD, Liu Y, Butticello M, et al. A DNA hypomethylation signature predicts antitumor activity of LSD1 inhibitors in SCLC. Cancer Cell. 2015;28:57-69.

139. Wu SC, Li LS, Kopp N, Montero J, Chapuy B, Yoda A, Christie AL, Liu H, Christodoulou A, van Bodegom D, et al. Activity of the type II JAK2 inhibitor CHZ868 in B cell acute lymphoblastic leukemia. Cancer Cell. 2015;28:29-41.

140. Cerezo M, Lehraiki A, Millet A, Rouaud F, Plaisant M, Jaune E, Botton T, Ronco C, Abbe P, Amdouni $\mathrm{H}$, et al. Compounds triggering ER stress exert anti-melanoma effects and overcome BRAF inhibitor resistance. Cancer Cell. 2016;29:805-19.

141. Veschi V, Liu Z, Voss TC, Ozbun L, Gryder B, Yan C, Hu Y, Ma A, Jin J, Mazur SJ, et al. Epigenetic siRNA and chemical screens identify SETD8 inhibition as a therapeutic strategy for p53 activation in high-risk neuroblastoma. Cancer Cell. 2017;31:50-63.

142. Huang X, Motea EA, Moore ZR, Yao J, Dong Y, Chakrabarti G, Kilgore JA, Silvers MA, Patidar PL, Cholka A, et al. Leveraging an NQO1 bioactivatable drug for tumor-selective use of poly(ADP-ribose) polymerase inhibitors. Cancer Cell. 2016;30:940-52.

143. Wang L, Yu Y, Chow DC, Yan F, Hsu CC, Stossi F, Mancini MA, Palzkill T, Liao $L$, Zhou $S$, et al. Characterization of a steroid receptor coactivator small molecule stimulator that overstimulates cancer cells and leads to cell stress and death. Cancer Cell. 2015:28:240-52.

144. Chauhan D, Tian Z, Nicholson B, Kumar KG, Zhou B, Carrasco R, McDermott IL, Leach CA, Fulcinniti M, Kodrasov MP, et al. A small molecule inhibitor of ubiquitin-specific protease-7 induces apoptosis in multiple myeloma cells and overcomes bortezomib resistance. Cancer Cell. 2012:22:345-58.

145. Chen W, Hill H, Christie A, Kim MS, Holloman E, Pavia-Jimenez A, Homayoun $F$, Ma $Y$, Patel N, Yell $P$, et al. Targeting renal cell carcinoma with a HIF-2 antagonist. Nature. 2016;539:112-7. 
146. Bono F, De Smet F, Herbert C, De Bock K, Georgiadou M, Fons P, Tjwa M, Alcouffe C, Ny A, Bianciotto M, et al. Inhibition of tumor angiogenesis and growth by a small-molecule multi-FGF receptor blocker with allosteric properties. Cancer Cell. 2013;23:477-88.

147. Sakamoto H, Tsukaguchi T, Hiroshima S, Kodama T, Kobayashi T, Fukami TA, Oikawa N, Tsukuda T, Ishii N, Aoki Y. CH5424802, a selective ALK inhibitor capable of blocking the resistant gatekeeper mutant. Cancer Cell. 2011;19:679-90.

148. Gumireddy K, Reddy MV, Cosenza SC, Boominathan R, Baker SJ, Papathi N, Jiang J, Holland J, Reddy EP. ON01910, a non-ATP-competitive small molecule inhibitor of PIk1, is a potent anticancer agent. Cancer Cell. 2005;7:275-86.

149. Plescia J, Salz W, Xia F, Pennati M, Zaffaroni N, Daidone MG, Meli M, Dohi T, Fortugno P, Nefedova $Y$, et al. Rational design of shepherdin, a novel anticancer agent. Cancer Cell. 2005;7:457-68.

150. Solit DB, Garraway LA, Pratilas CA, Sawai A, Getz G, Basso A, Ye Q, Lobo JM, She Y, Osman I, et al. BRAF mutation predicts sensitivity to MEK inhibition. Nature. 2006;439:358-62.

151. Visentin B, Vekich JA, Sibbald BJ, Cavalli AL, Moreno KM, Matteo RG, Garland WA, Lu Y, Yu S, Hall HS, et al. Validation of an anti-sphingosine-1-phosphate antibody as a potential therapeutic in reducing growth, invasion, and angiogenesis in multiple tumor lineages. Cancer Cell. 2006;9:225-38.

152. Thomas EK, Cancelas JA, Chae HD, Cox AD, Keller PJ, Perrotti D, Neviani $P$, Druker BJ, Setchell KD, Zheng Y, et al. Rac guanosine triphosphatases represent integrating molecular therapeutic targets for BCR-ABL-induced myeloproliferative disease. Cancer Cell. 2007;12:467-78.

153. Nickeleit I, Zender S, Sasse F, Geffers R, Brandes G, Sorensen I, Steinmetz H, Kubicka S, Carlomagno T, Menche D, et al. Argyrin a reveals a critical role for the tumor suppressor protein p27(kip1) in mediating antitumor activities in response to proteasome inhibition. Cancer Cell. 2008;14:23-35.

154. Hahn CK, Berchuck JE, Ross KN, Kakoza RM, Clauser K, Schinzel AC, Ross L, Galinsky I, Davis TN, Silver SJ, et al. Proteomic and genetic approaches identify Syk as an AML target. Cancer Cell. 2009;16:281-94.

155. Schimmer AD, Welsh K, Pinilla C, Wang Z, Krajewska M, Bonneau MJ, Pedersen IM, Kitada S, Scott FL, Bailly-Maitre B, et al. Small-molecule antagonists of apoptosis suppressor XIAP exhibit broad antitumor activity. Cancer Cell. 2004;5:25-35.

156. Tran C, Ouk S, Clegg NJ, Chen Y, Watson PA, Arora V, Wongvipat J, Smith-Jones PM, Yoo D, Kwon A, et al. Development of a secondgeneration antiandrogen for treatment of advanced prostate cancer. Science. 2009;324:787-90

157. Andersen RJ, Mawji NR, Wang J, Wang G, Haile S, Myung JK, Watt K, Tam T, Yang YC, Banuelos CA, et al. Regression of castrate-recurrent prostate cancer by a small-molecule inhibitor of the amino-terminus domain of the androgen receptor. Cancer Cell. 2010;17:535-46.

158. Raj L, Ide T, Gurkar AU, Foley M, Schenone M, Li X, Tolliday NJ, Golub TR, Carr SA, Shamji AF, et al. Selective killing of cancer cells by a small molecule targeting the stress response to ROS. Nature. 2011;475:231-4.

159. Mason JM, Lin DC, Wei X, Che Y, Yao Y, Kiarash R, Cescon DW, Fletcher GC, Awrey DE, Bray MR, et al. Functional characterization of CFI-400945, a Polo-like kinase 4 inhibitor, as a potential anticancer agent. Cancer Cell. 2014;26:163-76.

160. Han B, Park D, Li R, Xie M, Owonikoko TK, Zhang G, Sica GL, Ding C, Zhou J, Magis AT, et al. Small-molecule BCl2 BH4 antagonist for lung cancer therapy. Cancer Cell. 2015;27:852-63.

161. Girotti MR, Lopes F, Preece N, Niculescu-Duvaz D, Zambon A, Davies L, Whittaker S, Saturno G, Viros A, Pedersen M, et al. Paradox-breaking RAF inhibitors that also target SRC are effective in drug-resistant BRAF mutant melanoma. Cancer Cell. 2015;27:85-96.

162. Flaveny CA, Griffett K, El-Gendy Bel D, Kazantzis M, Sengupta M, Amelio AL, Chatterjee A, Walker J, Solt LA, Kamenecka TM, Burris TP. Broad anti-tumor activity of a small molecule that selectively targets the Warburg effect and lipogenesis. Cancer Cell. 2015;28:42-56.

163. Chen YN, LaMarche MJ, Chan HM, Fekkes P, Garcia-Fortanet J, Acker MG, Antonakos B, Chen CH, Chen Z, Cooke VG, et al. Allosteric inhibition of SHP2 phosphatase inhibits cancers driven by receptor tyrosine kinases. Nature. 2016;535:148-52.

164. Storm EE, Durinck S, de Sousa e Melo F, Tremayne J, Kljavin N, Tan C, Ye X, Chiu C, Pham T, Hongo JA, et al. Targeting PTPRK-RSPO3 colon tumours promotes differentiation and loss of stem-cell function. Nature. 2016:529:97-100
165. Anderson DJ, Le Moigne R, Djakovic S, Kumar B, Rice J, Wong S, Wang J, Yao B, Valle E, Kiss von Soly S, et al. Targeting the AAA ATPase p97 as an approach to treat cancer through disruption of protein homeostasis. Cancer Cell. 2015;28:653-65.

166. Veitonmaki N, Hansson M, Zhan F, Sundberg A, Lofstedt T, Ljungars A, Li ZC, Martinsson-Niskanen T, Zeng M, Yang Y, et al. A human ICAM-1 antibody isolated by a function-first approach has potent macrophage-dependent antimyeloma activity in vivo. Cancer Cell. 2013;23:502-15.

167. Milhollen MA, Thomas MP, Narayanan U, Traore T, Riceberg J, Amidon BS, Bence NF, Bolen JB, Brownell J, Dick LR, et al. Treatment-emergent mutations in NAEbeta confer resistance to the NEDD8-activating enzyme inhibitor MLN4924. Cancer Cell. 2012;21:388-401.

168. Etchin J, Montero J, Berezovskaya A, Le BT, Kentsis A, Christie AL, Conway AS, Chen WC, Reed C, Mansour MR, et al. Activity of a selective inhibitor of nuclear export, selinexor (KPT-330), against AML-initiating cells engrafted into immunosuppressed NSG mice. Leukemia. 2016;30:190-9.

169. Alves F, Borchers U, Padge B, Augustin H, Nebendahl K, Kloppel G, Tietze LF. Inhibitory effect of a matrix metalloproteinase inhibitor on growth and spread of human pancreatic ductal adenocarcinoma evaluated in an orthotopic severe combined immunodeficient (SCID) mouse model. Cancer Lett. 2001;165:161-70.

\section{Submit your next manuscript to BioMed Central and we will help you at every step:}

- We accept pre-submission inquiries

- Our selector tool helps you to find the most relevant journal

- We provide round the clock customer support

- Convenient online submission

- Thorough peer review

- Inclusion in PubMed and all major indexing services

- Maximum visibility for your research

Submit your manuscript at www.biomedcentral.com/submit
Biomed Central 